\title{
Energy saving in industry
}

\author{
I U Rakhmonov ${ }^{1}$, V Ya Ushakov ${ }^{2}, N$ N Niyozov ${ }^{l}, N_{N}$ Kurbonov $^{l}$, M Mamutov $^{3}$ \\ ${ }^{1}$ Tashkent state technical university named after Islam Karimov, Tashkent, Uzbekistan \\ ${ }^{2}$ Tomsk Polytechnic University, Russia \\ ${ }^{3}$ Karakalpak State University
}

\begin{abstract}
The article discusses the basic principles of energy saving in industry and methods for identifying and assessing the reserves of energy savings in industrial enterprises. The necessity of new complex solutions to this problem has been substantiated by developing integrated algorithms containing solutions for the rational use of energy resources of enterprises of various industries.
\end{abstract}

\section{Introduction}

An active energy saving policy is one of the key issues of technical progress, the solution of which is associated with the implementation of large-scale comprehensive programs to reduce the energy intensity of the national income.

This policy is especially relevant for the Republic of Uzbekistan, since with the rise in energy prices, the energy component in the cost of industrial products increases sharply, which affects its competitiveness [1-3].

The concept of the profitability of saving energy resources in comparison with increasing their production takes into account the bulk of the economic losses incurred by the state in the form of unrealizable reserves for saving energy resources.

The situation is aggravated by the fact that failure to take timely and appropriate measures to conserve fuel and energy resources will ultimately inevitably lead to severe economic consequences.

Taking this into account, it is necessary to proceed from an extremely unfavorable, but quite real situation when solving a wide range of economic, organizational and technical measures designed to ensure a sustainable increase in the efficiency of energy use in industry.

The most important role in solving the problem of energy saving belongs to the industry, which is a diversified and multilevel production, which consumes more than half of all energy resources and has the main reserves for saving energy resources, and such reserves that can be managed [4-7].

Therefore, industrial enterprises should become the primary objects of research.

The main areas of research:

- identification of patterns of change in electrical loads of electric drives when changing the operating mode of technological equipment;

- carrying out measurements of energy indicators on the operating equipment of various industries;

- drawing up the corresponding mathematical models and normative energy characteristics of the main technological units in order to optimize their operating modes;

- assessment of the influence of energy, technological and operational factors on electrical loads, absolute and specific power consumption;

- the use of modern mathematical methods for the analysis and forecasting of the energy performance of industrial enterprises.

The scale of these studies is visible not only from the individual features of each enterprise, which includes electric power, electrothermal and electrotechnological production processes, but also from the specifics of each unit and process.

The current level of scientific and technological progress in the field of energy saving must meet the highest requirements for the quality of analysis, calculation and forecasting of energy indicators, based on in-depth studies of modes of electrical loads and electricity consumption using the appropriate mathematical apparatus and using automated systems for accounting, monitoring and management of energy consumption [8-12].

Studies have shown that without a proper set of mathematical methods and an appropriate bank of algorithms that enhance the functionality of existing systems for accounting, monitoring and management of energy consumption, the problems of energy conservation in industry cannot be adequately solved.

Expanding the scope of research and implementation of work on the rational use of energy resources ultimately comes down to managing the energy intensity of products. In this process, a special place is occupied by the determination of the dependence of the energy intensity of products on the electrical, technological and operational parameters of industrial production, taking into account their specific features.

To identify the final results, a systematic analysis has been 
adopted, which makes it possible to provide a comprehensive solution to the task, taking into account the whole variety of interrelated factors and events.

In general, for the "unit - enterprise or association" complex, the research and calculation scenario was developed in the following logical sequence: unit, shop, enterprise, association (association), power system control room [13].

The control parameters are identified, taking into account the operating mode and production characteristics of the investigated object and the factors affecting the energy intensity indicators. In particular, the mode of operation in time; continuous mode of continuous operation; variable mode; product characteristics (single, homogeneous, heterogeneous); characteristics w operating mode of the main components of the technological process (compressed air, water, oxygen, etc.); inter production links; a set of measures for energy saving [14-20].

Mathematical models of specific power consumption have been developed for each type of product (by divisions and enterprise), providing for the influence of relevant factors on them. Taking into account the operation of units and workshops and their time parameters, the electricity consumption required for the release of a given volume of products and its energy consumption are determined.

At each stage of work, reserves of energy savings are identified, the implementation of which must be taken into account. From the general calculation scheme, the power of the units participating in the maximum hours of the power system should be allocated [21-24].

In accordance with the scenario, the initial decomposition of the system of specific energy consumption is performed, with the help of which the main subtasks are identified.

The decomposition diagram shows the indicator of specific electrical consumption (e) of a unit that produces dissimilar products $\left(\Pi_{1}, \Pi_{2}, \ldots, \Pi_{n}\right)$ with hourly productivity $\left(A_{1}, A_{2}, \ldots, A_{n}\right)$. The diagram includes the power consumption of the unit $(\mathrm{P})$, the average power per cycle for each type of product $\left(P_{a v 1}^{c}, P_{a v 2}^{c}, \ldots, P_{a v_{n}}^{c}\right)$ and the power of equipment for auxiliary needs $\left(P_{\text {sup }}\right)$, the cycle time $\left(t_{1}, t_{2}, \ldots, t_{n}\right)$, the number of cycles per hour $\left(m_{1}, m_{2}, \ldots, m_{n}\right)$, as well as the electricity consumption for the production of each type of product $\left(W_{1}, W_{2}, \ldots, W_{n}\right)$.

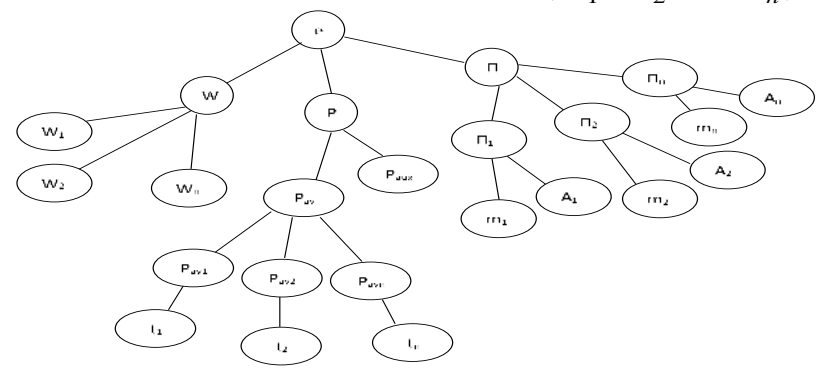

Fig. 1. Scheme of decomposition of the system of specific power consumption

The corresponding decomposition is developed for the workshop, enterprise and association.

For each subtask, a corresponding "tree of goals" is built, which includes the whole complex of influencing indicators (factors) and their relationships. It is necessary to take into account the logical sequence of the analysis and calculation of the energy intensity of products typical for units of any type and purpose. For units, all calculations must begin with determining the power consumption.

The first stage in solving this problem is the assessment of the indicated connections for the aggregates.

Let's consider the most difficult case: the unit operates in an alternating mode and produces dissimilar products. Initial data for the calculation: the production cycle, consisting of periods of work (load), idle and production pause. Each cycle has its own power consumption. Within each cycle, almost all power-consuming units operate auxiliary mechanisms with their own mode of operation and power consumption (average value) [25-31].

Based on the measurements, we find the average power consumption per cycle.

Knowing the unit's output, we obtain a mathematical model of the average power consumption per cycle:

$$
P_{a v}=\frac{K}{t_{p}}\left[W_{a u x}^{u}\left(1 \pm f_{i}\right)+\delta A^{c}\left(1 \pm \gamma_{i}\right)\right], \quad k W
$$

where $\mathrm{K}$ - is the number of cycles in the calculated period; $t_{p}$ - calculated period;

$f_{i}, \gamma_{i}$ - accordingly, the resulting values of factors, affecting the consumption of power for auxiliary needs and productivity;

$W_{\text {aux }}^{c}{ }^{-}$power consumption for auxiliary needs of the unit per cycle;

$A^{c}$ - average hourly productivity of the unit per cycle;

$\delta$ - coefficient representing a constant component of the specific energy consumption.

Next, the power consumption for the calculated period and the specific power consumption for the manufactured products are determined: $W=K\left[W_{\text {aux }}^{c}\left(1 \pm f_{i}\right)+\delta A^{c}\left(1 \pm \gamma_{i}\right)\right], \quad k W h /$ calculated period $d=K \frac{W_{a u x}^{c}\left(1 \pm f_{i}\right)}{A^{c}\left(1 \pm \gamma_{i}\right)}+\delta, \quad k W h /$ unit of production

In addition to the scenario for the unit and shops, a scenario has also been developed for the upper levels of management enterprises, amalgamations (associations) and the power system control center. These scenarios, according to the existing scheme (tree of goals), should be developed for each type of production that produces both single and homogeneous and heterogeneous products. At the same time, a differentiated block method for calculating and analyzing the energy intensity of products developed at the institute is used, which includes indicators of specific power consumption and specific consumption of raw materials and semi-finished products per unit of final product [2]. On the basis of system analysis, methods have also been developed for identifying and managing reserves of energy savings, which are obtained through the implementation of such measures as reducing electricity losses 8 to the power supply system, increasing the efficiency of units and mechanisms, compensating for reactive power, etc. In particular, a mathematical interpretation of the size of the savings reserve electricity as a result of a decrease in material consumption (raw materials and semi-finished products) when receiving the final product can be represented by the following formula: 
$\Delta W=Z\left[\sum_{i=1}^{n-1} d_{i} q_{i}-\sum_{i=1}^{n-1}\left(d_{i}\left(q_{i}-\Delta q_{i}\right)\left(1 \pm \sum_{1}^{m} f(t)\right], \quad k W h\right.\right.$

Where $Z$ - end products;

$q_{i}$ - specific consumption of processed products (raw materials, semi-finished products per unit of final product);

$\Delta q_{i}$ - the value of the specific reduction in the amount of processed products per unit of final product;

$d_{i}$ - specific power consumption per unit of semi-finished product of the $i$-th production unit;

$n$ - number of production units;

$m$ - the number of energy technology and operational factors affecting the energy intensity of products;

\section{$t$ - factors.}

\section{Conclusions}

Thus, the following conclusions can be drawn:

- the paper presents the basic principles of energy conservation in industry and methods for identifying and assessing reserves of energy savings at industrial enterprises;

- the whole range of energy saving tasks can be solved at two levels of industrial production:

lower level - unit or technological line;

the upper level - workshop or factory, and the enterprise as a whole;

- the need for new complex solutions to this problem has been substantiated by developing integrated algorithms containing solutions to problems for the rational use of energy resources of enterprises of various industries.

\section{References}

1. F.A. Khoshimov. Optimization of the use of energy resources in the textile industry. T. - Sub, $2005-252$ p.

2. Koptsev L.A., Koptsev A.L. Rationing and forecasting of electricity consumption at an industrial enterprise // Industrial energy. 2011. №. 1. P.18-23.

3. Batsova S. V. Organization of rationing of electricity at an industrial enterprise. Economic incentives for the rational use of electricity / S. V. Batsova // Casting and metallurgy: scientific and production journal. - 2010. - №3 (56). - S. 131 133.

4. Chegodaev AI Mathematical methods of analysis of expert assessments // Bulletin of the Samara State University of Economics. 2010. № 2 (64). S. 130-135.

5. F.A.Hoshimov, I.I.Bakhadirov, M.S.Kurbanbayeva, N.A.Aytbayev. Development of specific standards of energy consumption by types of produced products of the spinning product // RSES 2020. E3S Web of Conferences. 216 (2020) 01169. https://doi.org/10.1051/e3sconf/202021601169

6. F.A.Hoshimov, I.I.Bakhadirov, A.A.Alimov, M.T.Erejepov. Forecasting the electric consumption of objects using artificial neural networks // E3S Web of Conferences. 216 (2020)

01170 .

https://doi.org/10.1051/e3sconf/202021601170

7. R.Karimov. Study of the state of the issue of increasing the quality of electric energy in the power supply systems // RSES 2020. E3S Web of Conferences. 216 (2020) 01163. https://doi.org/10.1051/e3sconf/202021601163

8. Usmanov E.G. Stability in a parallel resonant circuit with active load // RSES 2020. E3S Web of Conferences. 216 (2020) 01160. https://doi.org/10.1051/e3sconf/202021601160
9. Usmanov E.G., Khusanov B.M. Phase relations in resonant circuits with a wide falling section on the amplitude characteristic // RSES 2020. E3S Web of Conferences. 216 (2020) 01161. https://doi.org/10.1051/e3sconf/202021601161 10. A.Taslimov, F.Rakhimov, L.Nematov, N.Markaev, A.Bijanov, R.Yunusov. Economic load intervals for selecting $10 \mathrm{kV}$ cable cross-sections for agricultural consumers // CONMECHYDRO - 2020. IOP Conf. Series: Materials Science and Engineering. $883 \quad$ (2020) 012102. doi:10.1088/1757-899X/883/1/012102

11. A.Taslimov, M.Melikuziev, O.Matchonov, M.Ruzinazarov and M.Nasirov. Development of standard cable cross-sections of rural electrical networks // CONMECHYDRO - 2020. IOP Conf. Series: Materials Science and Engineering. $883 \quad$ (2020) 012105. doi:10.1088/1757-899X/883/1/012105

12. I.Bakhadirov, N.Markaev, G.Aslanova, R.Tanatarov, S.Makhmuthonov. Differentiated tariffs of electricity for the improvement of steelmaking Uzbekistan // CONMECHYDRO - 2020. IOP Conf. Series: Materials Science and Engineering. $883 \quad$ (2020) 012121. doi:10.1088/1757-899X/883/1/012121

13. A.D.Taslimov, A.S.Berdishev, F.M.Rakhimov and A.A.Yuldashev. Optimal tendency of selecting cable crosssections for agricultural electrical networks // ICMSIT-2020. Journal of Physics: Conference Series. 1515 (2020) 022056. doi:10.1088/1742-6596/1515/2/022056

14. Abduraxim Berdishev, Abdurakhim Taslimov, Bakhtiyor Melikuziev and Alibi Bijanov. Reliability indicators of $10 \mathrm{kV}$ cable lines in rural areas // FORM-2020. IOP Conf. Series: Materials Science and Engineering. 869 (2020) 011001. doi:10.1088/1757-899X/869/1/011001

15. A.D.Taslimov. Selection of a complex of parameters of distribution electric networks with respect to technical limitations // ENERGY-21. E3S Web of Conferences. 209 (2020) 07013. https://doi.org/10.1051/e3sconf/202020907013 16. K.M.Reymov, G.R.Rafikova, L.A.Nematov, Sh.Esemuratova. Existing condition and prospects of making power balance and managing load of electric consumers in uzbek power system // ENERGY-21. E3S Web of Conferences. $\quad 209 \quad 07015$. https://doi.org/10.1051/e3sconf/202020907015

17. A.D.Taslimov, F.M.Rakhimov, A.O.Norkulov, A.A.Yuldashev. Research of the optimum scale of standard sections of agricultural purpose lines // E3S Web of $\begin{array}{llll}\text { Conferences. } & 216 & \text { (2020) } & 01158 .\end{array}$ https://doi.org/10.1051/e3sconf/202021601158

18. A.D.Taslimov., M.V.Melikuziev, A.M.Najimova, A.A.Alimov. Economic load intervals for selection of cable sections for agricultural purpose // E3S Web of Conferences. 216 (2020)

01159.

https://doi.org/10.1051/e3sconf/202021601159

19. Olimjon Toirov, Allabergan Bekishev, Sardor Urakov and Utkir Mirkhonov E3S Web of Conferences 216, 01116 (2020), https://doi.org/10.1051/e3sconf/202021601116

20. Hadha Afrisal, Budi Setiyono, Muhammad Fahmi Yusuf, Rose Mutiara Suin, Olimjon Toirov 2020 7th International Conference on Information Technology, Computer, and Electrical Engineering (ICITACEE), pp. 41-46 (2020), https://doi.org/10.1109/ICITACEE50144.2020.9239228

21. Baratov B., Toshov J., Baynazov U. Method of calculating the gear ratios of the cones of tricone drill bits // 
E3S Web Conf., Volume 201, 01012, 2020, Ukrainian School of Mining $\quad$ Engineering - 2020. https://doi.org/10.1051/e3sconf/202020101012

22. Haqberdiev A., Toshov J. Analysis of the control system of electric motors of the running gear of self-propelled mine cars used in complex mining and technological conditions // E3S Web of Conferences 216, 01135 (2020), Rudenko International Conference "Methodological problems in reliability study of large energy systems" (RSES 2020), https://doi.org/10.1051/e3sconf/202021601135

23. A.N.Rasulov, M.R.Ruzinazarov, N.Toirova, T.Sh.Alibekova. Graphical-analytical method for constructing load characteristics // RSES 2020. E3S Web of Conferences. $216 \quad$ (2020) 01171. https://doi.org/10.1051/e3sconf/202021601171

24. Rakhmonov I U, Tovbaev A N, Nematov L A and Alibekova T Sh 2020 Development of forecasted values of specific norms for the issues of produced products in industrial enterprises Journal of Physics: Conference Series 1515 doi:10.1088/1742-6596/1515/2/022050

25. E.Usmanov, A.Rasulov, M.K.Bobojanov, R.Ch.Karimov. Non-contact voltage relay for switching windings of a boost transformer (E3S Web of Conferences, 139, 01079, 2019), https://doi.org/10.1051/e3sconf/201913901079

26. Karimov R.Ch., Bobojanov M.K., Rasulov A.N., Usmanov E.G. Controlled switching circuits based on nonlinear resistive elements (E3S Web of Conferences, 139, 01039, 2019), https://doi.org/10.1051/e3sconf/201913901039 27. Toshov J.B. The questions of the dynamics of drilling bit on the surface of well bottom// Arch. Min. Sci. - Poland. - Vol. 61 (2016), № 2, P. 279-287. DOI 10.1515/amsc-2016-0020

28. I.U.Rakhmonov, K.M.Reymov. Statistical models of renewable energy intermittency // RSES 2020. E3S Web of $\begin{array}{llll}\text { Conferences. } & 216 & \text { (2020) } & 01167 .\end{array}$ https://doi.org/10.1051/e3sconf/202021601167

29. I.U.Rakhmonov, N.N.Kurbonov. Analysis of automated software for monitoring energy consumption and efficiency of industrial enterprises // E3S Web of Conferences. 216 (2020) 01178. https://doi.org/10.1051/e3sconf/202021601178

30. F.A.Hoshimov, I.U.Rakhmonov, N.N.Niyozov. Technology to reduce energy costs in the electric steel melting shop // ENERGY-21. E3S Web of Conferences. 209 (2020) 07017. https://doi.org/10.1051/e3sconf/202020907017

31. I.U.Rakhmonov, F.A.Hoshimov. Development of an algorithm for evaluating the dominant factors that have the greatest impact on the energy intensity of products // ENERGY-21. E3S Web of Conferences. 209 (2020) 07018. https://doi.org/10.1051/e3sconf/202020907018 